\title{
METHODOLOGY OF HAZARDS IDENTIFICATION IN CONSTRUCTION WORK COURSE
}

\author{
Bożena Hola \\ Institute of Building Engineering, Wrocław University of Technology, Wybrzeże Wyspiańskiego 27, \\ 50-370 Wroctaw, Poland \\ E-mail: bozena.hola@pwr.wroc.pl \\ Received 20 Oct. 2009; accepted 26 Oct. 2010
}

\begin{abstract}
The building industry is characterised by high variety and variability of working processes and work environment conditions, which is conductive to accidents at work. It is pointed out that the process of analyzing hazards in construction work should correspond to the successive changes in the state of the civil structure being erected and to the associated changes in the state of the production system. The starting-point for identifying hazards and determining the place and time of their occurrence should be a correctly drawn up graphic schedule of construction work.
\end{abstract}

Keywords: occupational hazards, civil structure, production process structure, accident rate factors, accident indices, graphic schedule of construction work.

\section{Introduction}

The increasing accident rates and accident seriousness indices in the Polish building industry, as it is evident from statistical data (Central Statistical Office 19932008), indicate that more attention should be paid to planning and carrying out construction work in accordance with the safety standards (Hoła 2006, 2007, 2008, 2009a, 2009b).

Work safety in the building industry, examined from different angles, is the subject of research projects in many countries in the world (Fredericks et al. 2005; Hassanein et al. 2008; Idoro 2008; Seo et al. 2008; Liaudanskiené et al. 2009, 2010). This shows that the compliance with work safety standards on the building site is an important problem in these countries. Safe work conditions are the result of proper prevention which is dictated by the following factors: obligations arising from the law, the moral obligation, the human being's selfpreservation instinct and profit. In order to reduce the accident rate on the building site, first all the factors which might pose a hazard to workers (Carter and Smith 2006; Hadad et al. 2007; Shapira and Lyachin 2009; Shapira and Smicha 2009) and the mechanisms leading to accidents (Hoła 2008; Kleiner et al. 2008; Lee et al. 2009) should be identified.

Factors posing a threat to the worker are present in each work environment. For both technical and economic reasons, it is not possible to completely eliminate them. But they can be reduced to an acceptably low level. For this purpose, models which make it possible to predict potential hazards in the course of construction work are developed (Hadicusumo and Rowlinson 2002; Hoła 2007; Tantesevi and Akinci 2009). By identifying the potential hazards already before the commencement of construction work one can take proper preventive measures.

In Poland, in order to improve work safety on the building site, the obligation to make a safety and health protection plan (SHPP) before the commencement of construction work has been introduced (Construction Law 1994), whereby the Polish regulations concerning work safety on the building site have been brought into line with the requirements contained in the EU directive (Directive 92/57/EEC 1992). The main aim of SHPP is to indicate hazards which may arise in the course of carrying out construction work.

Considering the fact that work safety conditions on the building site change as construction work progresses, an original methodology for identifying hazards has been developed. The methodology takes into account the building process factors changing with the work schedule. Having this knowledge about the hazards and the place and time of their occurrence one can take preventive measures to reduce the risk of accidents at work on the building site.

\section{Hazard definition}

A hazard is a specific situation connected with a production process or a work process and is characterised by such a configuration or state of factors of this process, which may result in an accident at work or an occupational disease (Carter and Smith 2006; Hoła 2008). Thus a hazard is any factor which can cause loss of life or health.

The sources of hazards in work processes are technical factors (i.e.: machines, devices, materials), organisational factors (e.g. the sub-contractor system of carrying out construction work) and human factors (e.g. errors 
made by the worker). Furthermore, hazards in construction work may be generated by the external environment and other civil structures situated within or outside the building site.

Occupational hazards connected with construction work conducted in specific work environment conditions are the subject of, among others, the papers (Hadad et al. 2007; Hassanein et al. 2008; Hoła 1999). Their authors identified the hazards connected with the erection of new civil structures (Hadad et al. 2007; Hassanein et al. 2008), the repair and modernisation of the existing structures and demolition work (Hoła 1999). In the latter paper attention was drawn to a very important factor which might be the source of hazards in repair and upgrading work, i.e. the condition of the structure being repaired. A wrong diagnosis of the condition of the structure being repaired may be the cause of a structural failure or collapse. A model of the development of events leading to collapses of civil structures during their service life is the subject of the papers (Vaidogas and Juocevicius 2008, 2009; Zavadskas and Vaidogas 2008, 2009).

In order to explain the dependences between the building process and the generated hazards, a building process model, in the form of a developing microstructure, has been developed.

\section{Model of production process in building industry}

Each production process is a result of the changes taking place in the production system. As a result of the technological operations performed on the object being produced the state of the latter, the state of the particular elements of the production system and the state of the work environment change. Production systems are dynamic systems. Time is an inherent attribute of each dynamic system. The features of the individual system elements and of the system as a whole undergo changes with time. The current system state generates the next state in accordance with the accepted technological and organisational rules. The model of the production process in the building industry, in the form of a developing system microstructure, is shown in Fig. 1.

According to the assumed formulation, the production system is perceived as a set of the particular states which the civil structure under construction successively goes through. The set of system states can be expressed by the formula:

$$
P=\left\{P\left(t_{i}\right): i=1,2, \ldots, n\right\},
$$

at:

$$
\begin{gathered}
P\left(t_{i}\right) \subset\left\{M\left(t_{i}\right), U\left(t_{i}\right), O\left(t_{i}\right), D T\left(t_{i}\right), S T\left(t_{i}\right), S O\left(t_{i}\right), W\left(t_{i}\right), \Omega\left(t_{i}\right)\right\}, \\
i=1, \ldots, n,
\end{gathered}
$$

where: $t_{i}$ - the instant in which the state of the production system (the building site) changes, $n-$ the number of system state changes as a result of which the civil structure is erected, $P-$ a set of states of the civil structure, which includes the particular stages in the process of its erection, $M-$ a set of building materials needed for the particular stages in the construction of the civil structure, $U-$ a set of machines and equipment used in the different stages of building the civil structure, $O-$ a set of workers doing the particular tasks and activities, $D T-$ a set of technical activities (e.g.. processing, transportation, storage, control and maintenance) resulting in a change in the state of the civil structure, $S T$ - a set of technological rules specifying the way in which the production object is to be processed, $S O$ - a set of organisational rules describing the size of the particular sets, the inferior and superior rules, the place and time of carrying out the particular activities, $W-$ a set of places in space, where construction work is done, $\Omega-$ a set of dependencies among the above mentioned production process factors.

As a result of the carried out construction work the system passes from state $P\left(t_{i}\right)$ to state $P\left(t_{i+1}\right)$.

$$
\omega_{p}: P\left(t_{i}\right) \rightarrow P\left(t_{i+1}\right), i=1,2, \ldots, n .
$$

The transformation of the system from state $P\left(t_{i}\right)$ to state $P\left(t_{i+1}\right)$ causes changes in the attributes of the particular distinguished sets of process material components $(M, U$, $O)$, technical activities (DT), obligatory technological rules $(S T)$ and obligatory organizational rules $(S O)$. Also the place in space $(W)$, where construction work is conducted changes.

\section{Relations between hazards and construction work course}

Production systems are controllable systems. This means that a person or a properly programmed technical device can act on the production system to make it perform its intended function. The graphic construction work schedule is a tool which aids construction process control. The construction work schedule also reflects the organisational and technological rules assumed during construction work planning.

As the construction work progresses and time passes, the elements of the sets specified in the developing system microstructure undergo quantity and quality changes. Each transition of the civil structure from state $P\left(t_{i}\right)$ to state $P\left(t_{i+1}\right)$ is accompanied by an appropriate set of possible hazards.

$$
\left\{P\left(t_{i}\right) \rightarrow P\left(t_{i+1}\right)\right\}=Z\left(t_{i}\right) \quad i=1,2, \ldots, n,
$$

where: $Z\left(t_{i}\right)$ - a set of hazards being the consequence of the transition of the system from state $P\left(t_{i}\right)$ to state $P\left(t_{i+1}\right)$.

At the particular stages of the building process the set of hazards to human life and health is a sum of hazards generated by the simultaneously conducted construction works and hazards penetrating into the work environment from the surroundings $\left(\mathrm{S}^{\prime}\left(\mathrm{t}_{\mathrm{i}}\right)\right)$. An exemplary construction work schedule and the corresponding transition from state $P\left(t_{i}\right)$ to state $P\left(t_{i+1}\right)$ is shown in Fig. 2. 


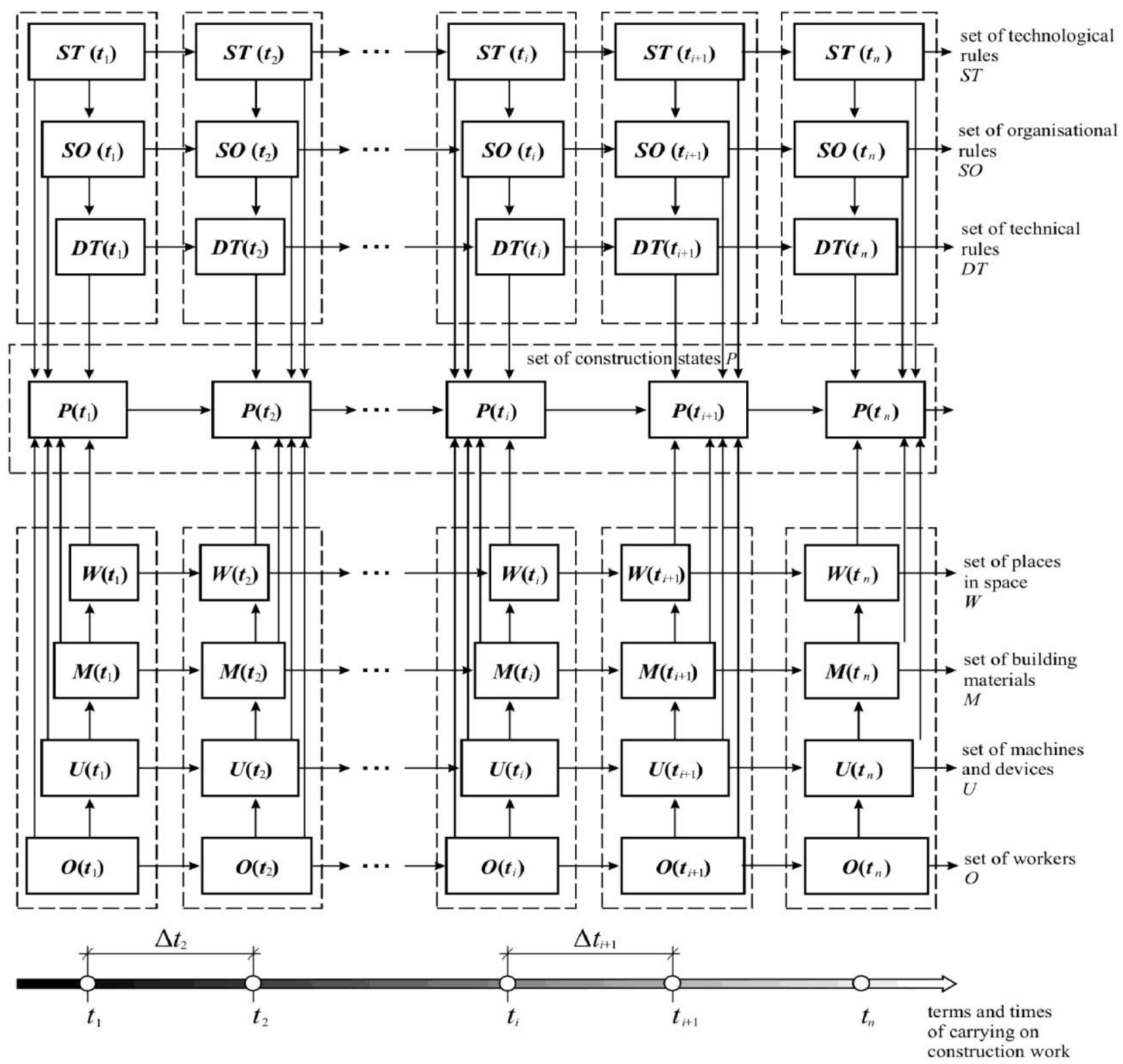

Fig. 1. Model of production process in building industry, in form of developing system microstructure

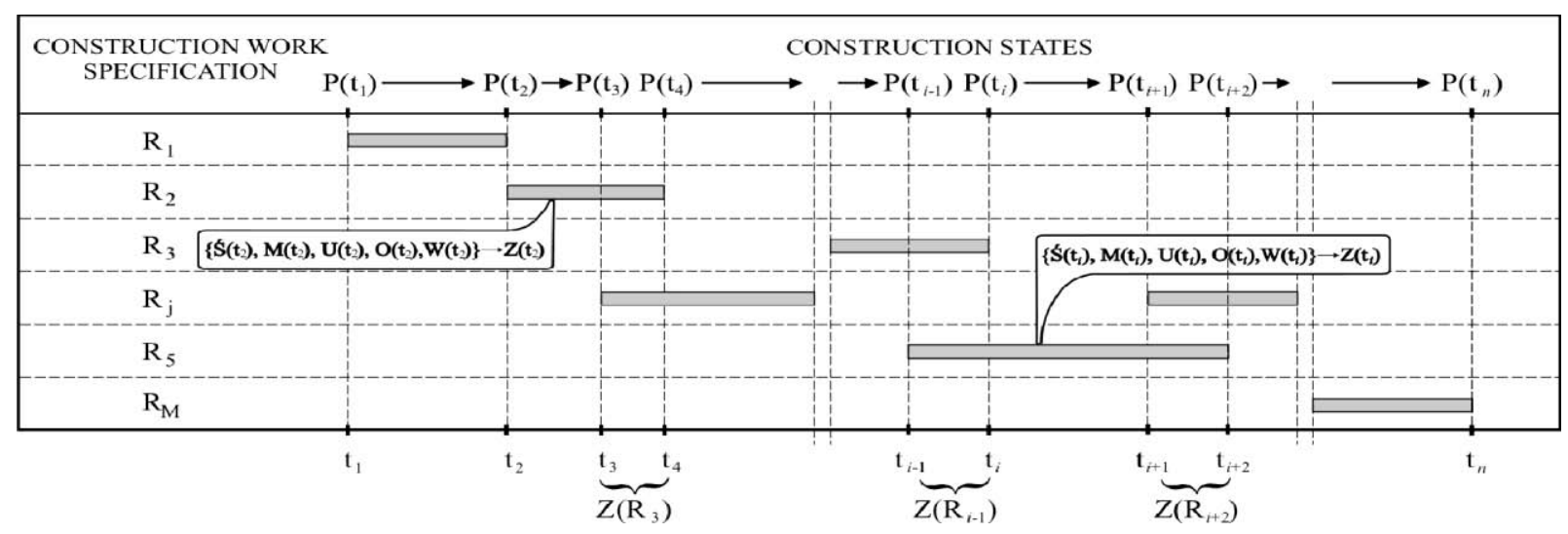

Fig. 2. Exemplary construction work schedule which takes into account changes in production system state and corresponding changes in sets of hazards 


\section{Methodology of determining hazards in construction work course}

\subsection{Assumptions}

The methodology for identifying hazards in the course of construction work is based on the following assumptions:

- as part of a construction project, set $R$ of construction works need to be carried out:

$$
R=\left\{R_{j}: j=1, \ldots j, . . m\right\}
$$

- each construction work $R_{j} \in R$ at $j=1, \ldots m$,

is described by a set of information such as: the commencement date, the completion date, the duration, the kind of work, the place of the construction work, the machines and equipment, the building materials needed to do the work, the workers who are to do the work. The set of information concerning the particular construction works can be presented in the form of this vector:

$$
R_{j}=\left[\begin{array}{lllllll}
T_{j, r} & T_{j, z} & t_{j} & M_{j} & U_{j} & O_{j} & W_{j}
\end{array}\right],
$$

where: $T_{j, r}$ - the date of starting construction work $R_{j}$, $T_{j, z}$ - the date of finishing construction work $R_{j}, r-$ the commencement of the work, $z$ - the end of construction work, $t_{j}$ - the duration of construction work $R_{j} ; t_{j}=T_{j, z^{-}}$ $T_{j, r}, M_{j}$ - building materials necessary to do construction work $R_{j}, U_{j}$ - machines and equipment necessary to do construction work $R_{j}, O_{j}$ - the set of people doing construction work $R_{j}, W_{j}$ - the place in space, where construction work $R_{j}$ is conducted.

- The set of data on all the construction works conducted within a building project can be presented in the form of the matrix:

$$
X=\left[\begin{array}{ccccccc}
T_{1, r} & T_{1, z} & t_{1} & M_{1} & U_{1} & O_{1} & W_{1} \\
T_{2, r} & T_{2, z} & t_{2} & M_{2} & U_{2} & O_{2} & W_{2} \\
\ldots & \ldots & \ldots & \ldots & \ldots & \ldots & \ldots \\
T_{j, r} & T_{j, z} & t_{j} & M_{j} & U_{j} & O_{j} & W_{j} \\
T_{m, r} & T_{m, z} & t_{m} & M_{m} & U_{m} & O_{m} & W_{m}
\end{array}\right]
$$

The elements of data matrix $X$ constitute a set of the features of all the construction works as a result of which a civil structure will be erected. Set $X$ can be divided into two subsets: subset $\mathrm{T}$ and subset $\mathrm{K}$. Subset $T$ contains starting dates $T_{j, r}$ and finishing dates $T_{j, z}$ of all the construction works $R_{j}$ for $j=1, \ldots, m$ while subset comprises other data;

$$
\begin{gathered}
K=\left\{K_{j}: j=1, \ldots, m\right\}, \\
X=T \cup K, \\
X=\left[\begin{array}{cc}
T_{1, r} & T_{1, z} \\
T_{2, r} & T_{2, z} \\
\ldots & \ldots \\
T_{j, r} & T_{j, z} \\
T_{m, r} & T_{m, z}
\end{array}\right]+\left[\begin{array}{ccccc}
t_{1} & M_{1} & U_{1} & O_{1} & W_{1} \\
t_{2} & M_{2} & U_{2} & O_{2} & W_{2} \\
\ldots & \ldots & \ldots & \ldots & \ldots \\
t_{j} & M_{j} & U_{j} & O_{j} & W_{j} \\
t_{m} & M_{m} & U_{m} & O_{m} & W_{m}
\end{array}\right],
\end{gathered}
$$

$$
T \cap K=\varnothing .
$$

- For set $T$ a number which defines its size, i.e. the cardinality of set $T$, is defined as follows:

$$
\bar{T}=2 m \text {. }
$$

- There exists set $I \subseteq N$, where: $N-$ is a set of natural numbers.

\subsection{Mathematical description of proposed methodology}

- Elements $T_{j, k} \in T$ for $j=1, \ldots, m$ and $k=r \vee z$ are ordered into a non-decreasing finite sequence of numerical values $\left(n_{i}\right)_{i=1}^{2 m}$.

- Assignment relations $f: N \rightarrow T$ hold between the elements of sets $N$ and $T$ so that:

$$
\begin{gathered}
\forall n_{1}, n_{2} \in N\left[n_{1}>n_{2} \Rightarrow f\left(n_{1}\right) \geq f\left(n_{2}\right)\right], \\
N=\{1, \ldots ., 2 m\}
\end{gathered}
$$

- The arguments of function $f$ are the elements of set $T$, whereby:

$$
f\left(n_{i}\right)=t_{i}=T_{j . k}: k=r \vee k=z: j=1, \ldots, m
$$

and

$$
i=1, \ldots, 2 m \text {. }
$$

The created sequence of values $f\left(n_{i}\right)$, marked on the axis of time on the graphic construction work schedule, corresponds to the dates of the events which cause a change in the state of the building process. Analysing the course of events in the building process one can identify stages in it and assign sets of hazards, which may occur in the course of the particular works, to the stages.

- Hazards in construction work are generated by the following production process elements:

$$
\begin{gathered}
\left\{M\left(t_{i}\right), U\left(t_{i}\right), O\left(t_{i}\right), W\left(t_{i}\right), \dot{S}\left(t_{i}\right)\right\} \rightarrow Z\left(t_{i}\right), \\
i=1, \ldots, 2 m,
\end{gathered}
$$

where: $M\left(t_{i}\right)$ - a set of building materials necessary to carry out the construction works in time interval $\left\langle t_{i}, t_{i+1}\right\rangle, U\left(t_{i}\right)$ - a set of machines and equipment necessary to carry out the construction works in time interval $\left\langle t_{i}, t_{i+1}\right\rangle, O\left(t_{i}\right)$ - a set of people needed to carry out the construction works in time interval $\left\langle t_{i}, t_{i+1}\right\rangle$, $W\left(t_{i}\right)$ - a set of places in space, where the construction works are to be carried out in time interval $\left\langle t_{i}, t_{i+1}\right\rangle$, $S\left(t_{i}\right)$ - hazards penetrating into the work environment from the surroundings.

In the time interval from $t_{i}$ to $t_{i+1}$ the building process is in state $P\left(t_{i}\right)$ to which set of hazards $Z R\left(t_{i}\right)$ corresponds: 


$$
\left\{P\left(t_{i}\right) \rightarrow P\left(t_{i+1}\right)\right\}=Z\left(t_{i}\right) \quad i=1,2, \ldots, 2 m .
$$

Set of hazards $Z\left(t_{i}\right)$ is a sum of the hazards generated by the particular simultaneously conducted construction works. Hence

$$
\begin{gathered}
\forall i=1, \ldots, 2 m, \\
\forall j=1, \ldots, m, \\
\left(t_{i} \in\left\langle T_{j, r}, T_{j, z}\right\rangle\right) \Rightarrow Z\left(t_{i}\right) \bigcup_{j=1}^{m} Z\left(t_{j}\right), \\
\left(t_{i} \notin\left\langle T_{j, r}, T_{j, z}\right\rangle\right) \Rightarrow Z\left(t_{i}\right)=\varnothing .
\end{gathered}
$$

A block diagram of the procedure for identifying hazards in the course of construction work is shown in Fig. 3.

\subsection{Factors generating hazards}

The identification of hazards is a process whose main aim is to determine the existing hazards or to predict possible dangerous situations or events. The factors generating hazards in construction work were systematized on the basis of analyses of the processes and work environment conditions which occur in the building industry. The sources of hazards in construction work are as follows:

- elements of the production process,

- elements of the surroundings of construction work.

The factors generating hazards in the course of construction work in the building industry are the following attributes of the construction process:

- the kind of conducted construction work,

- the properties of the building materials used,

- the machines and equipment used,

- the place of construction work,

- the adopted rules of construction work organisation,

- the conditions stemming from the building site location.

Fig. 4 shows a scheme of implication relations among construction work attributes and hazards which may arise in the course of carrying out construction work.
Knowing the sources of hazards one can identify the potential hazards and develop a proper work safety plan.

The above methodology will be the basis for a computer program, which combined with an electronic catalogue of hazards, will greatly facilitate drawing up safety and health protection plans.

\subsection{Exemplary application of proposed methodology}

The proposed methodology was used to determine the hazards which may arise during the laying of foundations for a residential building. Set $R$ is made up of three kinds of construction work:

$$
R=\left\{R_{j}: j=1, \ldots ., 3\right\},
$$

where: $j=1$ - making a wide excavation, $j=2$ - making a foundation slab, $j=3-$ application of horizontal damp-proofing.

The construction work schedule shown in Fig. 5 and the specifications of the materials, machines and equipment, work teams and construction work places shown in Table 1 are the basis for defining hazards and the time when they will arise.

There were to be no other civil structures or aboveground or underground installations in the surroundings.

Changes in the state of the conducted construction work will occur at the instants in which the particular works specified in the schedule begin or end. Matrix $T$ has this form:

$$
T=\left[\begin{array}{cc}
T_{r, 1} & T_{z, 1} \\
T_{r, 2} & T_{z, 2} \\
T_{r, 3} & T_{z, 3}
\end{array}\right]=\left[\begin{array}{cc}
0 & 10 \\
5 & 15 \\
20 & 25
\end{array}\right]
$$

Elements of matrix $T$ ordered into non-decreasing sequence $\left(n_{i}\right)_{i=1}^{2 m}$ and values $f\left(n_{i}\right)$ of this sequence are shown in Table 2. By comparing the sequence of events with the construction work schedule and the catalogue of hazards one can determine sets of hazards in the particular time intervals. Table 3 contains sets of hazards and the time intervals in which the identified hazards may become active as a result of the conducted foundation work.

Table 1. Specifications of technical means used to carry out construction work

\begin{tabular}{c|l|l|l|c|c}
\hline $\begin{array}{c}\text { Number of } \\
\text { work } j\end{array}$ & $\begin{array}{c}\text { Specification of } \\
\text { work }\end{array}$ & \multicolumn{1}{|c|}{$\begin{array}{c}\text { Materials } \\
M_{j}\end{array}$} & $\begin{array}{c}\text { Machines and equipment } \\
U_{j}\end{array}$ & $\begin{array}{c}\text { Work } \\
\text { team } O_{j}\end{array}$ & $\begin{array}{c}\text { Place of construction work } \\
W_{j}\end{array}$ \\
\hline 1 & wide excavation & excavated material & pull shovel & 2 & 2 m below ground \\
\hline 2 & foundation slab & $\begin{array}{l}\text { concrete mixture, } \\
\text { reinforcement }\end{array}$ & $\begin{array}{l}\text { concrete pump, concrete } \\
\text { delivery truck, vibrator }\end{array}$ & 4 & 2 m below ground \\
\hline 3 & $\begin{array}{l}\text { horizontal } \\
\text { damp-proofing }\end{array}$ & $\begin{array}{l}\text { torch-on membrane, } \\
\text { propane/butane gas }\end{array}$ & $\begin{array}{l}\text { crane, gas-fired burners, } \\
\text { gas cylinders }\end{array}$ & 4 & 2 m below ground \\
\hline
\end{tabular}

Table 2. Instants at which changes in state of conducted construction work occur

\begin{tabular}{c|c|c|c|c|c|c}
\hline Event $i$ & 1 & 2 & 3 & 4 & 5 & 6 \\
\hline Terms of sequence $\left(n_{i}\right)_{i=1}^{2 m}$ & $T_{r, 1}$ & $T_{r, 2}$ & $T_{z, 1}$ & $T_{z, 2}$ & $T_{r, 3}$ & $T_{z, 3}$ \\
\hline Values $f\left(n_{i}\right)$ & 0 & 5 & 10 & 15 & 20 & 25 \\
\hline
\end{tabular}




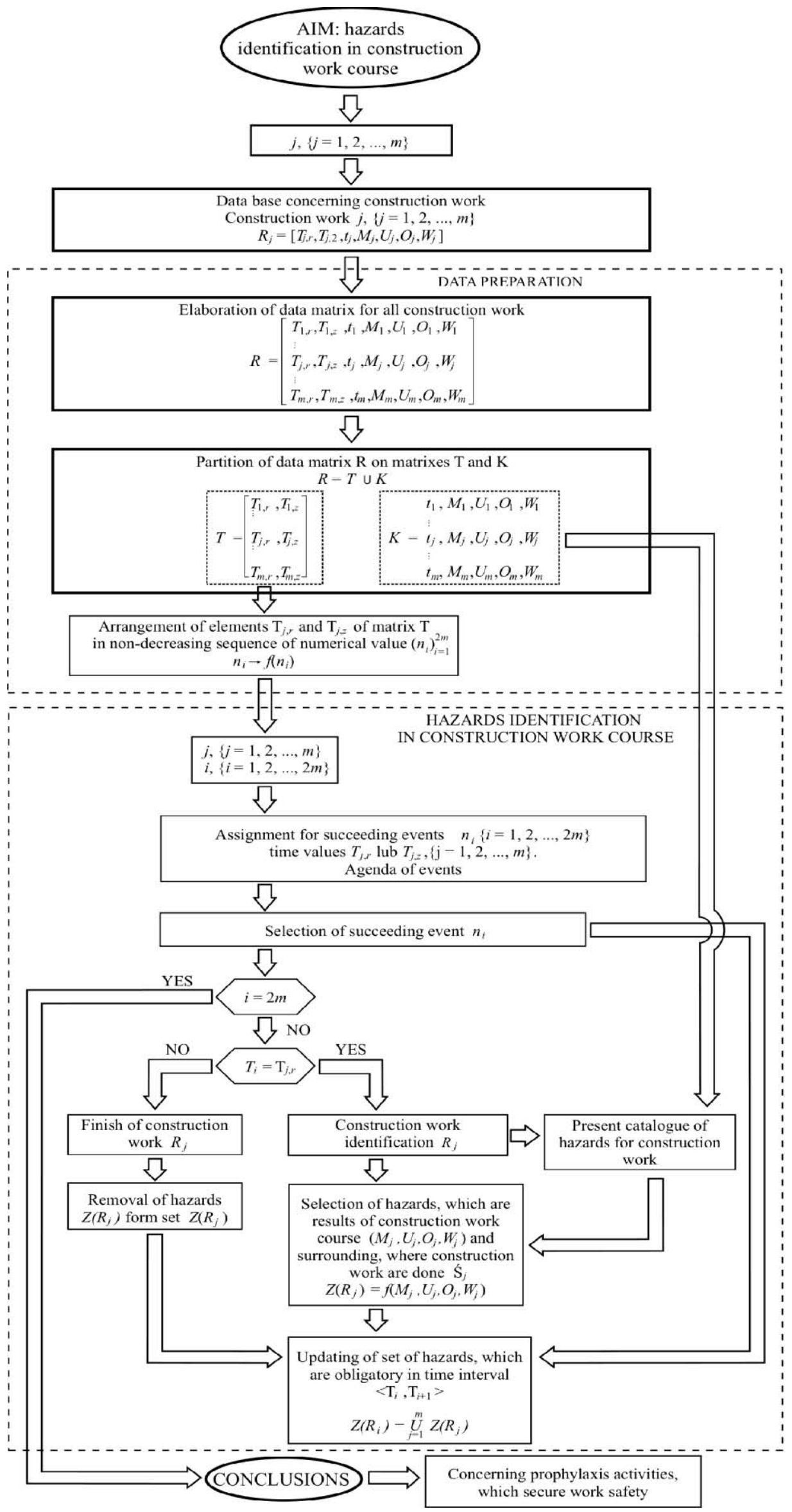

Fig. 3. Block diagram of procedure for identifying hazards in course of construction work 


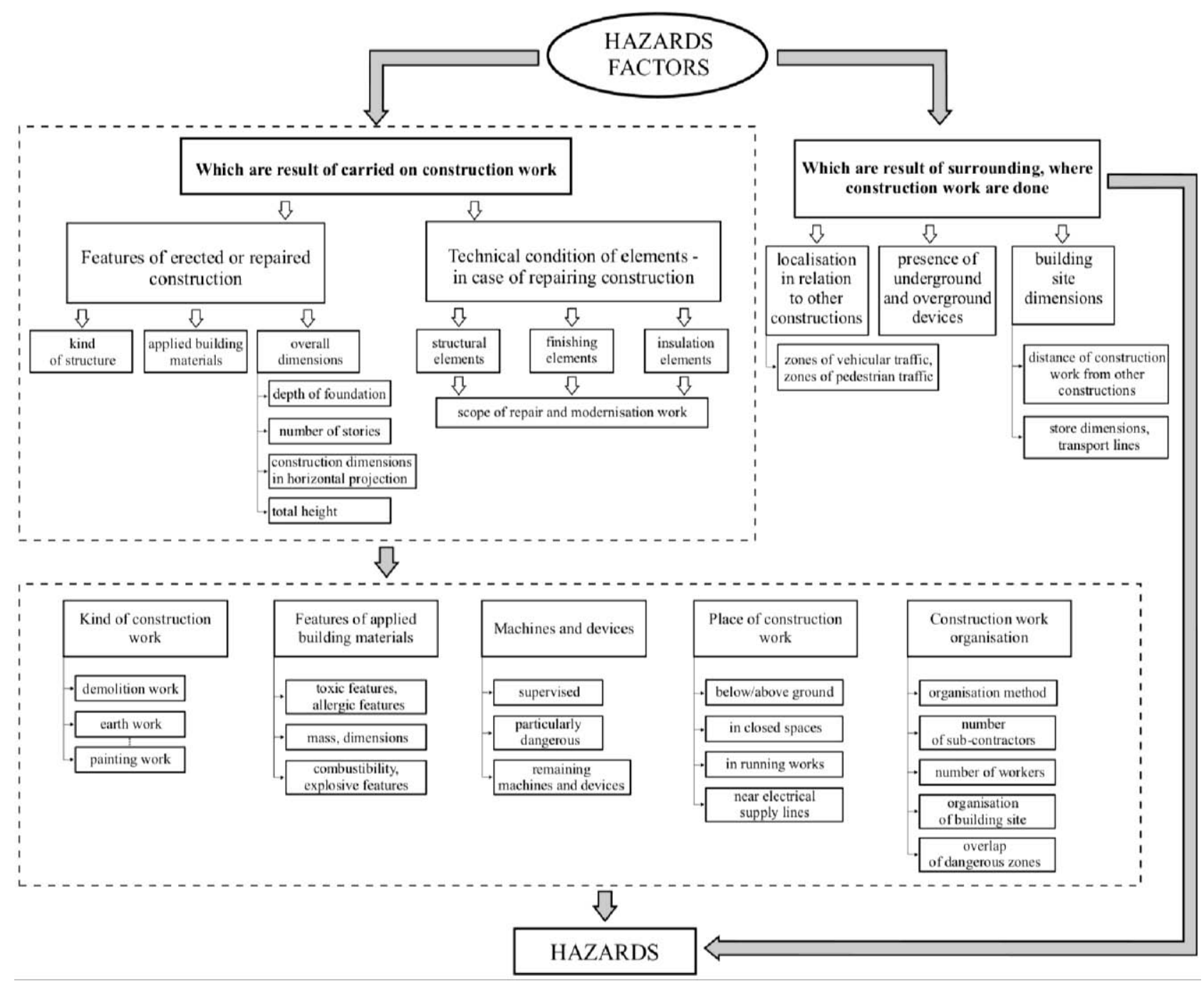

Fig. 4. Scheme of implication relations among construction work attributes and hazards which may occur while carrying out construction work

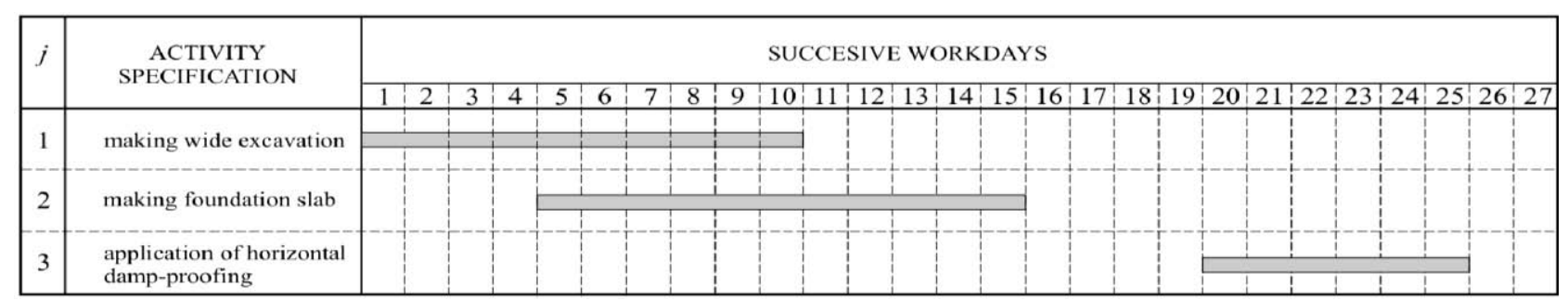

Fig. 5. Exemplary construction work schedule

Table 3. Identified sets of hazards and corresponding time intervals

\begin{tabular}{c|c|c|l}
\hline$i$ & $i+1$ & $\begin{array}{c}\text { Time interval } \\
<T_{i}, T_{i+1}>\end{array}$ & \multicolumn{1}{c}{ Set of hazards $Z\left(R_{i}\right)$} \\
\hline 1 & 2 & $<0,5>$ & $\begin{array}{l}\text { falling down excavation, being knocked down by excavator or truck, being buried under exca- } \\
\text { vated material }\end{array}$ \\
\hline 2 & 3 & $<5,10>$ & $\begin{array}{l}\text { falling down excavation, being knocked down by excavator or truck, being buried under exca- } \\
\text { vated material, danger from sharp reinforcement bars, being struck by pump hose, electrocu- } \\
\text { tion during consolidation }\end{array}$ \\
\hline 3 & 4 & $<10,15>$ & $\begin{array}{l}\text { falling down excavation, being buried under excavated material, danger from sharp reinforce- } \\
\text { ment bars, being struck by pump hose, electrocution during consolidation }\end{array}$ \\
\hline 4 & 5 & $<15,20>$ & falling down excavation \\
\hline 5 & 6 & $<20,25>$ & falling down excavation, suffering burn during torching of membrane, explosion of gas cylinder \\
\hline
\end{tabular}




\section{Conclusion}

The paper highlights the fact that in building production, hazards which may be the cause of accidents at work, change in the course of construction work. This is the consequence of changes taking place in such process elements as machines, equipment, building materials and workers. Also the place of construction work changes in space. Furthermore, hazards may penetrate into the building site from its surroundings. Therefore the process of analyzing hazards in construction work should correspond to the process of changes in the state of the structure being erected or in the state of the conducted construction work and the associated changes in the state of the elements of the production system in which the civil structure is erected.

Considering the above, a procedure facilitating the analysis of factors which generate hazards has been developed. An essential component of the procedure is a catalogue of hazards which includes possible conditions and variants of construction work realization. It was pointed out that hazards in construction work are connected with the properties of the civil structure being erected or the technical condition of the structure being repaired and they also stem from the surroundings in which the construction work is conducted.

A methodology of identifying hazards in the course of construction work, taking into account changes in process elements and construction work progress reflected in the graphic schedule, has been proposed.

\section{References}

Act of 7 July 1994, Construction law. Government Regulation and Law Gazett 207. Warsaw, 2003 (in Polish).

Carter, G.; Smith, S. D. 2006. Safety hazard identification on construction projects, Journal of Construction Engineering and Management 132(2): 197-205. doi:10.1061/(ASCE)0733-9364(2006)132:2(197)

Central Statistical Office 1993-2008. Accidents at Work in 1992-2007. Warsaw: GUS (in Polish).

Council Directive 92/57/EEC on the implementation of minimum safety and health requirements at temporary or mobile construction site.

Fredericks, T.; Abudayyeh, O.; Choi, S.; Wiersma, M.; Charles, M. 2005. Occupational Injuries and Fatalities in the Roofing Contracting Industry, Journal of Construction Engineering and Management 131(11): 1233-1240. doi:10.1061/(ASCE)0733-9364(2005)131:11(1233)

Hadad, Y.; Laslo, Z.; Ben-Yair, A. 2007. Safety Improvement by Eliminating Hazardous Combinations, Technological and Economic Development of Economy 13(2): 114-119.

Hadicusumo, B. H. W.; Rowlinson, S. 2002. Integration of Virtually real construction model and design-for-safetyprocess Database, Automation in Construction 11(5): 501-509. Elsevier. doi:10.1016/S0926-5805(01)00061-9

Hassanein, A. G.; Hanna, Ragaa, S. 2008. Safety Performance in the Egyptian Construction Industry, Journal of Construction Engineering and Management 134(6): 451-455. doi:10.1061/(ASCE)0733-9364(2008)134:6(451)

Hoła, B. 2009a. Dynamics of the Development of Accident Situation in Construction Industry with Reference to
Building Production Value, Archives of Civil Engineering 55(2): 255-264.

Hoła, B. 2009b. Methodology of Estimating of Accident Situation in Building Industry, Archives of Civil and Mechanical Engineering 9(1): 29-46.

Hoła, B. 2007. General Model of Accident Rate Growth in the Construction Industry, Journal of Civil Engineering and Management 13(4): 255-264.

Hoła, B. 2008. Qualitative and Quantitative Modelling of Accident Situation in Building Industry. Wrocław: Oficyna Wydawnicza Politechniki Wrocławskiej (in Polish).

Hoła, B. 2006. Development Tendency of Accident Situation in Building Construction, Archives of Civil and Mechanical Engineering 6(3): 3-14.

Hoła, B. 1999. Selected aspects of work safety in repair and modernization work, Przeglad Budowlany 6: 19-22 (in Polish).

Idoro, G. I. 2008. Health and Safety Management Efforts as Correlates of Performance in the Nigeria Construction Industry, Journal of Civil Engineering and Management 14(4): 277-285. doi:10.3846/1392-3730.2008.14.27

Kleiner, B, M.; Smith-Jackson, T.; Mills, III M. H.; O’Brien, M.; Haro, E. 2008. Design, Development, and Deployment of a Rapid Universal Safety and Health System for Construction, Journal of Construction Engineering and Management 134(4): 273-279. doi:10.1061/(ASCE)0733-9364(2008)134:4(273)

Lee, U.; Kim, J.; Cho, H., Kang, K. 2009. Development of a Mobile Safety Monitoring System for Construction Sites, Automation in Construction 18(3): 258-264. doi:10.1016/j.autcon.2008.08.002

Liaudanskienė, R.; Ustinovichius, L.; Bogdanovicius, A. 2009. Evaluation of Construction Processes Safety Solutions Using the TOPSIS Method, Inzinerine Ekonomika - Engineering Economics (4): 32-40.

Liaudanskienè, R.; Varnas, N.; Ustinovichius, L. 2010. Modelling the application of workplace safety and Heath act In Lithuanian Construction sector, Technological and Economic Development of Economy 16(2): 223-253. doi:10.3846/tede.2010.15

Seo, J. W.; Hyun, Ho Choi. 2008. Risk-Based Safety Impact Assessment Methodology for Underground Construction Projects in Korea, Journal of Construction Engineering and Management 134(1): 72-81. doi:10.1061/(ASCE)0733-9364(2008)134:1(72)

Shapira, A.; Lyachin, B. 2009. Identification and Analysis of Factors Affecting Safety of Construction Site with Tower Cranes, Journal of Construction Engineering and Management 135(1): 24-33. doi:10.1061/(ASCE)0733-9364(2009)135:1(24)

Shapira, A.; Simcha, M. 2009. AHP-Based Weighting of Factors Affecting Safety on Construction Sites with Tower Cranes, Journal of Construction Engineering and Management 135(4): 307-318. doi:10.1061/(ASCE)0733-9364(2009)135:4(307)

Tantesevi, K.; Akinci, B. 2009. Transformation of a 4D Product and Process Model to Generate Motion of Mobile Cranes, Automation in Construction 18(4): 458-468. doi:10.1016/j.autcon.2008.10.008

Vaidogas, E. R.; Juocevičius, V. 2008. Sustainable development and major industrial accidents: the beneficial role of riskoriented structural engineering, Technological and Economic Development of Economy 14(4): 612-627. doi:10.3846/1392-8619.2008.14.612-627 
Vaidogas, E. R.; Juocevičius, V. 2009. Assessment of Structures Subjected to Accidental Actions Using Crips and Uncertain Fragility Functions, Journal of Civil Engineering and Management 15(1): 95-104.

doi:10.3846/1392-3730.2009.15.95-104

Zavadskas, E. K.; Vaidogas, E. R. 2008. Bayesian reasoning in managerial decisions on the choice of equipment for the prevention of industrial accidents, Inzinerine Ekonomika Engineering Economics (5): 32-40.
Zavadskas, E. K.; Vaidogas, E. R. 2009. Multiattribute selection from alternative designs of infrastructure components for accidental situations, Computer-Aided Civil and Infrastructure Engineering 24(5): 346-358.

doi:10.1111/j.1467-8667.2009.00593.x

\section{RIZIKOS VEIKSNIŲ, ATLIEKANT STATYBOS DARBUS, ATPAŽINIMO METODIKA}

\section{B. Hola}

\section{Santrauka}

Statybos pramonei būdinga didelè darbo procesų ir darbo aplinkos sąlygų įvairovė bei kintamumas, o tai daro poveikị nelaimingiems atsitikimams darbe. Pažymètina, kad statybos darbų pavojų analizavimo procesas turi būti suderintas su statomo visuomeninio pastato būklès pokyčiais ir su ja susijusiais gamybos sistemos būklès pasikeitimais. Rizikos veiksnių atpažinimo pradžioje bei nustatant jų atsiradimo vietą ir laiką turetų būti tinkamai sudarytas statybos darbų kalendorinis planas.

Reikšminiai žodžiai: profesinė rizika, visuomeninès paskirties statinys, gamybos proceso struktūra, avaringumo veiksniai, avaringumo rodikliai, statybos darbų kalendorinis planas.

Bożena HOŁA. Doctor Habil. Eng, obtained her diploma in civil engineering at Wrocław University of Technology, Poland in 1976. Working in the Institute of Building Engineering at WUT, she has spent over 25 years doing research on construction process modelling, the managerial approach and safety and health protection at work. She is a member of PZITB (Polish Association of Civil Engineers and Technicians). 